\title{
Prevalence of Botrytis Cryptic Species in Strawberry Nursery Transplants and Strawberry and Blueberry Commercial Fields in the Eastern United States
}

Achour Amiri, ${ }^{\dagger}$ Washington State University, Tree Fruit Research and Extension Center, Wenatchee 98801; and Adrian I. Zuniga and Natalia A. Peres, University of Florida, Gulf Coast Research and Education Center, Wimauma 33598

\begin{abstract}
Botrytis isolates from strawberry transplants originating from Canada and the northern United States as well as isolates collected from strawberry and blueberry commercial fields in the southeastern United States were investigated for the frequency of Botrytis cinerea, other cryptic Botrytis spp. reported recently, and the transposable elements (TE) using six genetic markers. B. cinerea sensu stricto was predominant (94\%) in strawberry and blueberry in all surveyed regions. Botrytis group S, a newly reported clade on strawberry from Germany, was found at low frequencies $(6 \%)$ in strawberry in the United States and Canada and on blueberry isolates from Florida. Neither B. caroliniana nor B. pseudocinerea were detected in the U.S. or Canadian populations. Transposa isolates containing the TE boty and flipper accounted for $74 \%$ of 410 isolates studied herein. Isolates containing boty only or flipper only elements were found

at 21 and 2\%, respectively. However, boty isolates were predominant in the blueberry population with more than $50 \%$. The TE were found in B. cinerea and Botrytis group $\mathrm{S}$ at similar frequencies, except that flipper was more frequent $(10.7 \%$ ) in Botrytis group S, compared with $1.6 \%$ in B. cinerea. The sensitivity of 256 Botrytis isolates from the different genetic groups described above was evaluated to seven fungicides registered to control gray mold in commercial fields. Results indicate that $B$. cinerea and transposa isolates have higher resistance frequencies to almost all fungicides tested compared with the other Botrytis genotypes or species, whereas the TE flipper may be related to resistance to fludioxonil. Similarities observed between nursery and commercial field populations and their impact on gray mold development and management are discussed.
\end{abstract}

The genus Botrytis was separated from Sclerotinia in the early 19th century (Smith, 1900) and its relation to the Botryotinia family was established (Groves and Loveland 1953). Since then, its speciation, and species within, has been continuously redefined. Two decades ago, Beever and Weeds (2004) recognized at least 20 different species in the genus Botrytis and 10 additional species have been identified in the last decade (Walker 2016). The species Botrytis cinerea (teleomorph Botryotinia fuckeliana de Bary) remains one of the most studied species and is known for its unusual genetic variability. The species' variability has been linked to the mode of reproduction, including asexual and heterokaryotic reproduction (less often sexual reproduction); high genetic diversity, defined by its ability to undergo several mutational stages; the presence of multiple vegetative compatibility groups (Beever and Parkes 2003); and extrachromosomal genetic elements, including linear plasmids (Hiratsuka et al. 1987), mycoviruses (Castro et al. 2003; Kecskeméti et al. 2014), and transposable genetic elements (TE) (Diolez et al. 1995; Giraud et al. 1999). In recent years, studies revealed other Botrytis spp., coexisting with Botrytis cinerea, capable of causing gray mold on multiple crops. For example, B. pseudocinerea was differentiated from $B$. cinerea based on the vegetative incompatibility locus and was reported on grape, strawberry, tomato, and blueberry (Fournier et al. 2003; Johnston et al. 2014; Leroch et al. 2013; Saito et al. 2014). Other region-specific species such as B. caroliniana have been reported at very low frequencies on strawberry and blackberry in the Carolinas (Li et al. 2012). A new clade named Botrytis group $\mathrm{S}$ and a new species, B. fragariae, were reported to be widespread in German strawberry fields (Leroch et al. 2013; Rupp et al. 2017). Initially thought to be host specific, Botrytis group $\mathrm{S}$ was reported on other hosts recently (Kanetis et al. 2017; Konstantinou et al. 2015). The genetic variability within the Botrytis spp. has previously been defined based on the presence of TE. Boty and flipper, classified into class I (RNA-TE) and class II (DNA-TE)-type TE, respectively (Kidwell and Linch 2001), have

${ }^{\dagger}$ Corresponding author: A. Amiri; E-mail: a.amiri@wsu.edu

Accepted for publication 28 September 2017.

() 2018 The American Phytopathological Society been largely investigated in $B$. cinerea and used to characterize potential subgroups such as transposa and vacuma types (Giraud et al. 1999).

In Florida, gray mold is the major threat to strawberry production because of highly conducive weather conditions (i.e., adequate temperature and extended wetness) during the growing season from September to March. In the southeastern United States, strawberry is grown as an annual crop from transplants shipped annually from nurseries across Canada and the northern United States These transplants have been shown to carry latent infections of Botrytis spp. and other pathogens (Oliveira et al. 2013, 2017; Rahman et al. 2015) and, therefore, are a major primary inoculum source in commercial fields. It is likely that different subpopulations of Botrytis, selected in the nurseries under different weather and fungicide spray conditions, are introduced annually to the commercial strawberry fields. Moreover, the selection of new southern highbush varieties of blueberry, with few hours of chill requirement, has made Florida among the top leading producing states. The crop is spread throughout northern and central Florida (i.e., the main strawberry production region near the Gulf-coast area). In blueberry, especially on highbush cultivars, Botrytis spp. can cause severe blossom blight and significant yield reduction. Blueberry is a perennial crop on which introduction of exogenous Botrytis populations is expected to be lower compared with strawberry. However, depending on the cultivar, blueberry flowering occurs between February and May, which coincides for many early cultivars with the peak bloom period on strawberry. It is possible that a substantial amount of Botrytis inoculum released from strawberry fields is disseminated to neighboring blueberry fields. In addition, fungicide input is considerably lower compared with strawberry. The exact impact of such practices on the Botrytis population structure and the fungicide resistance phenotypes in blueberry fields is unknown. Therefore, this study aimed to investigate (i) the prevalence and distribution of different Botrytis spp. and genetic TE populations collected from strawberry in eastern North America and in blueberry Florida fields and (ii) assess their respective sensitivities to seven fungicides commonly used to control gray mold or blossom blight in strawberry and blueberry fields.

\section{Materials and Methods}

Collection and storage of Botrytis isolates. In total, 410 Botrytis isolates collected from strawberry (330) and blueberry (80) were used in this study. Isolates from strawberry included 20, 57, 243, 50, and 40 isolates collected in 2010, 2011, 2012, 2013, and 2014, 
respectively. Geographically, 340 and 70 strawberry isolates were collected from different states and provinces in the United States and Canada, respectively. In the United States, isolates were collected from California, North Carolina, South Carolina, and Florida, and Canadian isolates originated from nurseries in Nova Scotia, Ontario, and Quebec (Table 1). The 80 isolates from blueberry were collected from different blueberry fields in central Florida from March to June 2013. The 410 isolates included 65, 90, and 255 from flowers, leaves or stems, and fruit, respectively. For isolates from fruit, a small plug was taken from the inside lesions and transferred onto a general isolation medium (GI; $19 \mathrm{~g}$ of potato dextrose agar, $15 \mathrm{~g}$ of agar, $125 \mathrm{mg}$ of ampicillin, and $200 \mathrm{mg}$ of streptomycin per liter) and incubated for 4 days at $22^{\circ} \mathrm{C}$, and a 6-mm mycelial plug taken from the margin of GI plates was transferred to malt yeast extract agar (MYA) plates. Flowers and leaves were surface sterilized in $0.8 \%$ sodium hypochlorite for $2 \mathrm{~min}$, rinsed with sterile water, frozen at $-20^{\circ} \mathrm{C}$ overnight, incubated at $22^{\circ} \mathrm{C}$ for 5 days, and checked for the presence of Botrytis spp. using a stereoscope. Spores on Botrytis-like conidiophores were aseptically transferred to GI plates and grown as explained above. All isolates were grown on MYA until profuse sporulation was observed, single spored as described previously (Amiri et al. 2013), and stored as mycelial plugs in $20 \%$ glycerol at $-80^{\circ} \mathrm{C}$.

Genomic DNA extraction for Botrytis population structure. Isolates from $-80^{\circ} \mathrm{C}$ were freshly regrown on MYA for 7 to 10 days or until profuse sporulation was observed. Sporulating mycelia were harvested from half 60-mm MYA plates and transferred to lysing tubes and DNA was extracted using the FastDNA kit (MP Biomedical, Solon, $\mathrm{OH}$ ) following the manufacturer's protocol. The concentration and quality of DNA was checked using a spectrophotometer. DNA was diluted to $20 \mathrm{ng} / \mu \mathrm{l}$ and stored at $-20^{\circ} \mathrm{C}$ until used.

The genetic structure of Botrytis spp. was investigated based on six different markers (Table 2). The presence of TE boty and flipper, which have been used to distinguish the transposa and vacuma sympatric species of $B$. cinerea, was investigated as described previously (Levis et al. 1997; Ma and Michailides 2005). Both boty and flipper elements are present in transposa but absent in vacuma species (Diolez et al. 1995; Levis et al. 1997). The presence of B. pseudocinerea was detected by the mutation at codon 367 of the hch gene (Fournier et al. 2003), whereas the presence and Botrytis group $S$ was verified by the presence of a 21-bp insertion in the $m r r l$ gene (Leroch et al. 2013). The presence of the B. caroliniana, previously reported in the Carolinas, was investigated using specific markers amplifying different fragment sizes of the G3PDH gene (Li et al. 2012). The intergenic spacer (IGS) patterns were investigated using an IGS polymerase chain reaction (PCR) restriction fragment length polymorphism (RFLP), as described by (Kretschmer and Hahn 2008; Giraud et al. 1997). Restrictions were initially done with MspI and Hinp1I enzymes but the later was selected to conduct the study because it produced higher and consistent restriction profiles. All PCR amplifications and enzyme restrictions were conducted following the conditions described in Table 2.

Fungicide sensitivity tests. In all, 262 Botrytis isolates collected from Florida strawberry fields were tested for sensitivity to pyraclostrobin (Pyra), boscalid (Bosc), penthiopyrad (Penth), fluopyram (Flup), fludioxonil (Flud), fenhexamid (Fenh), and pyrimethanil (Pyri). Sensitivity was evaluated using a germ tube elongation inhibition assay on agar media amended with fungicides at doses reported previously to discriminate sensitive from resistant isolates. Sensitivities to Pyra, Fenh, and Flud were assessed on malt extract agar amended with 10, 50, and 0.1 and $10 \mu \mathrm{g} / \mathrm{ml}$, respectively (Weber and Hahn 2011). For Bosc, Penth, and Flup, sensitivity was assessed on yeast bacto acetate agar amended with 5, 3, and $2.5 \mu \mathrm{g} / \mathrm{ml}$, respectively. The $5 \mu \mathrm{g} / \mathrm{ml}$ for Bosc was adjusted from Leroch et al. (2013) whereas the discriminatory doses for Penth and Flup were determined in this study after isolates with different mutations in the $\mathrm{SdhB}$ subunit had been tested on multiple doses (Amiri et al. 2014, 2017). Sensitivity to Pyri was assessed

Table 1. Origin and number of Botrytis sp. isolates collected from strawberry and blueberry

\begin{tabular}{|c|c|c|c|c|c|c|c|c|}
\hline \multirow[b]{3}{*}{ Country } & \multirow[b]{3}{*}{ State or province } & \multirow[b]{3}{*}{ Host } & \multicolumn{6}{|c|}{ Number of isolates } \\
\hline & & & \multirow[b]{2}{*}{ Total } & \multicolumn{5}{|c|}{ Year of isolation } \\
\hline & & & & 2010 & 2011 & 2012 & 2013 & 2014 \\
\hline \multirow[t]{3}{*}{ Canada } & Ontario & Strawberry & 12 & $\ldots$ & $\ldots$ & 6 & 6 & $\ldots$ \\
\hline & Quebec & Strawberry & 30 & $\ldots$ & 8 & 10 & 15 & $\ldots$ \\
\hline & Nova Scotia & Strawberry & 27 & $\ldots$ & 8 & 8 & 9 & $\ldots$ \\
\hline \multirow[t]{5}{*}{ United States } & North Carolina & Strawberry & 13 & $\ldots$ & 5 & 8 & $\ldots$ & $\ldots$ \\
\hline & South Carolina & Strawberry & 18 & $\ldots$ & 8 & 10 & $\ldots$ & $\ldots$ \\
\hline & Florida & Blueberry & 80 & $\ldots$ & $\ldots$ & 80 & $\ldots$ & $\ldots$ \\
\hline & California & Strawberry & 10 & $\ldots$ & $\ldots$ & 1 & 9 & $\ldots$ \\
\hline & Florida & Strawberry & 220 & 20 & 28 & 120 & 11 & 40 \\
\hline Total & $\ldots$ & $\ldots$ & 410 & 20 & 57 & 243 & 50 & 40 \\
\hline
\end{tabular}

Table 2. Primer sequences and polymerase chain reaction conditions used to amplify multiple loci in this study

\begin{tabular}{|c|c|c|c|c|c|c|c|c|c|c|}
\hline \multirow[b]{2}{*}{ Marker } & & \multicolumn{2}{|r|}{ Primer } & \multicolumn{4}{|c|}{ Amplification $\left({ }^{\circ} \mathrm{C}-\mathrm{sec}\right)^{\mathrm{a}}$} & \multirow[b]{2}{*}{ Final Ext $\left({ }^{\circ} \mathrm{C}-\mathrm{min}\right)$} & \multirow[b]{2}{*}{$\mathbf{R F L P}^{\mathbf{b}}$} & \multirow[b]{2}{*}{ Reference } \\
\hline & & Name & Sequence $\left(5^{\prime}-3^{\prime}\right)$ & Den & Ann & Ext & Cyc & & & \\
\hline Boty & $\mathrm{F}$ & BotyF4 & CAGCTGCAGTATACTCGGGGA & $94-40$ & $68-40$ & $72-60$ & 40 & $72-10$ & $\ldots$ & $\begin{array}{l}\text { Ma and Michailides } \\
2005\end{array}$ \\
\hline & $\mathrm{R}$ & BotyR4 & GGTGCTCAAAGTGTTACGGGAG & & & & & & & \\
\hline Flipper & $\begin{array}{l}\mathrm{F} \\
\mathrm{R}\end{array}$ & $\begin{array}{l}\text { F300 } \\
\text { F1550 }\end{array}$ & $\begin{array}{l}\text { GCACAAAACCTACAGAAGA } \\
\text { ATTCGTTTCTTGGACTGTA }\end{array}$ & $94-40$ & $60-40$ & $72-60$ & 40 & $72-10$ & $\ldots$ & Levis et al. 1997 \\
\hline Mrrl & $\begin{array}{l}\mathrm{F} \\
\mathrm{R}\end{array}$ & $\begin{array}{l}\text { Mrr1-spez-f } \\
\text { Mrr1-spez-R }\end{array}$ & $\begin{array}{l}\text { TATCGGTCTTGCAGTCCGC } \\
\text { TTCCGTACCCCGATCTTCGGAA }\end{array}$ & $94-40$ & $58-50$ & $72-60$ & 35 & $72-5$ & $\ldots$ & Leroch et al. 2013 \\
\hline IGS & $\begin{array}{l}\mathrm{F} \\
\mathrm{R}\end{array}$ & $\begin{array}{l}\text { IGS1a } \\
\text { IGS1b }\end{array}$ & $\begin{array}{l}\text { TCCCGGTGAGCCTTTTA } \\
\text { CCATCGGCCAGTAATCCA }\end{array}$ & $95-60$ & $60-60$ & $72-150$ & 30 & $72-10$ & $\begin{array}{l}M s p \mathrm{I} \\
\text { HinfI }\end{array}$ & Giraud et al. 1997 \\
\hline$G 3 P H$ & $\begin{array}{l}F \\
F \\
R\end{array}$ & $\begin{array}{l}\text { G3PDH-F1 } \\
\text { G3PDH-F2 } \\
\text { G3PDH-R }\end{array}$ & $\begin{array}{l}\text { CGACCCGAGCTAATTTATGTCACGT } \\
\text { GGGTGTCAACAACGAGACCTACACT } \\
\text { ACCGGTGTCCGATGGGATGAT }\end{array}$ & $94-40$ & $56-30$ & $72-60$ & 32 & $72-5$ & $\ldots$ & Levis et al. 1997 \\
\hline $\mathrm{HcH}$ & $\begin{array}{l}\mathrm{F} \\
\mathrm{R}\end{array}$ & $\begin{array}{l}\text { hch-262 } \\
\text { hch-520L }\end{array}$ & $\begin{array}{l}\text { AAGCCCTTCGATGTCTTGGA } \\
\text { ACGGATTCCGAACTAAGTAA }\end{array}$ & $94-30$ & $55-90$ & $72-60$ & 30 & $72-10$ & HhaI & Fournier et al. 2003 \\
\hline
\end{tabular}

\footnotetext{
${ }^{a}$ Temperature and cycle duration used for polymerase chain reaction (PCR) amplifications: denaturation (Den), annealing (Ann), Extension (Ext), and number of cycles (Cyc)

${ }^{\mathrm{b}}$ Restriction fragment length polymorphism (RFLP) digestion of indicated PCR products was achieved following the manufacturers' protocols.
} 
on $0.5 \%$ sucrose agar with discriminatory doses of 1 and $25 \mu \mathrm{g} / \mathrm{ml}$ (Weber and Hahn 2011). Assays were conducted on 150-mm plates, which allowed testing for 42 isolates simultaneously. A transparent 42-section cellophane grid was attached to the bottom of the plates and $7 \mu \mathrm{l}$ of spore suspension of approximately $10^{6} \mathrm{spores} / \mathrm{ml}$ was placed in each section. Germination and germ tube elongation were evaluated after 18 to $24 \mathrm{~h}$ of incubation at $22^{\circ} \mathrm{C}$. Isolates were considered resistant if the germ tube length was a at least twice the conidium diameter.

Data analysis. Percent values of resistance frequencies in each genetic group containing boty, flipper, or both were log transformed and subjected to $\chi^{2}$ analyses. Resistance frequencies to different fungicides in different genetic groups were log transformed before analysis of variance and a mean separation was performed using Student's $t$ test. All analyses were conducted in JMP software (JMP statistical software, version 12.1.0; SAS Institute Inc., Cary, NC).

\section{Results}

Prevalence of Botrytis spp. and TE. Among the 330 isolates from strawberry, 93.6 and $6.4 \%$ were B. cinerea and Botrytis group S, respectively (Fig. 1). Geographically, the frequency of Botrytis group S was 6.1 and $7.4 \%$ in the United States and Canadian populations, respectively. Botrytis group S was found in the blueberry population from Florida at a frequency of $3.8 \%$, versus $96.2 \%$ of $B$. cinerea (Fig. 1). Neither B. pseudocinerea nor B. caroliniana were found among the strawberry or blueberry isolates tested in this study, regardless of the geographic origin.

The TEs boty and flipper were found in combination (transposa) or separately in a large majority of $B$. cinerea isolates. Thus, transposa isolates (flipper + boty) made up to $74.4 \%$ of strawberry populations followed by boty-only, vacuma, and flipper-only isolates at 21.7, 2.2, and $1.7 \%$, respectively (Fig. 2A). Geographically, the transposa group was predominant in all regions with somewhat similar frequencies, ranging from $64.7 \%$ in Canada to $79.4 \%$ in the United States. The frequency of boty isolates was the highest in Canada (33.8\%), two times $(15.3 \%)$ higher than in the United States (Fig. 2A). Isolates containing flipper element only were found in the U.S. strawberry population only at a low frequency of $4.1 \%$ (Fig. 2A). The vacuma group was found in the United States and Canada at frequencies of 1.2 and $1.5 \%$, respectively. Interestingly, the blueberry population from Florida was dominated by the boty isolates with $56.3 \%$ of isolates, whereas $43.8 \%$ were transposa (Fig. 2A). Flipper or vacuma types were not found in the blueberry population. The structure of Botrytis group $\mathrm{S}$ showed similar patterns compared with $B$. cinerea (Fig. 2B), with a predominance of transposa and boty isolates, even though the frequencies of flipper and vacuma groups were higher in group S compared with B. cinerea (Fig. 2B).

The organ from which the isolates were collected had some impact on the presence of the different Botrytis genotypes. Frequencies of $B$. cinerea and Botrytis group S were similar on leaves, fruit, or flowers but transposa isolates were significantly more frequent $(80 \%)$ on fruit compared with $46 \%$ on flowers (Table 3 ). On the other hand, boty isolates were significantly lower (12 to $26 \%$ ) on fruit compared

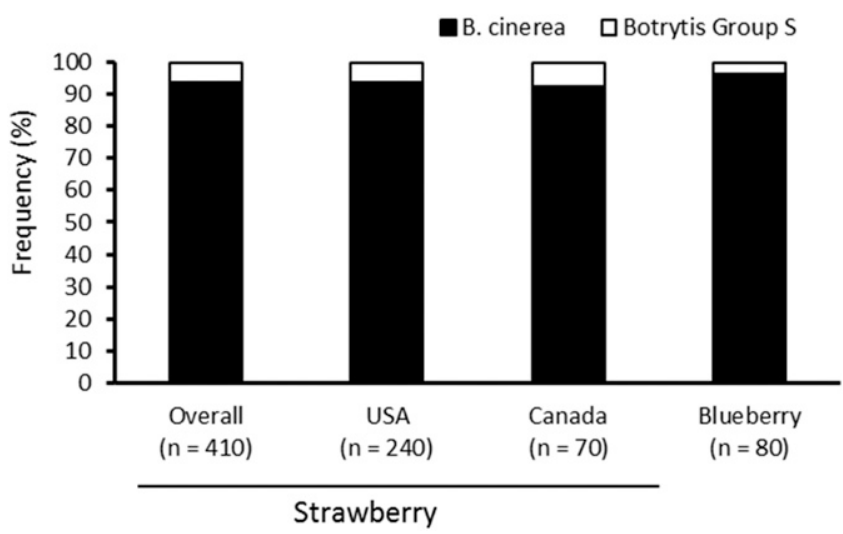

Fig. 1. Overall frequency of Botrytis cinerea and Botrytis group $S$ in a population of 410 Botrytis isolates from strawberry (330) and blueberry (80) fields in North America. with $53.2 \%$ on flowers, whereas vacuma isolates were not found on flowers and flipper isolates were only found on fruit (Table 3). The IGS-RFLP assay based on Hinp1I (HinfI) digestion of IGS fragments yielded six different electrophoretic patterns (data not shown). Although two patterns were predominant in strawberry and blueberry isolates, there was not a clear correlation between a given IGS pattern and the different Botrytis groups.

Fungicide sensitivities of $B$. cinerea and Botrytis group $S$ with different TE types. The frequency of isolates sensitive to all fungicides tested was significantly higher in Botrytis group S compared with B. cinerea (Fig. 3A). Resistance frequencies to Pyra and Bosc were significantly higher in $B$. cinerea and numerically higher for Fenh and Penth compared with Botrytis group S (Fig. 3A). Resistance frequencies for Pyri and reduced sensitivity to Flud were higher in Botrytis group $\mathrm{S}$ but not significantly different from $B$. cinerea.

There was some variability in resistance frequencies between isolates with different TE. The four vacuma isolates tested in this study were all resistant to Pyra, Bosc, and Pyri but sensitive to Fenh (data not shown). The transposa and boty isolates exhibited significantly higher resistance frequencies for Pyra, Bosc, Pyri, and Fenh compared with flipper isolates (Fig. 3B). Interestingly, reduced sensitivity to Flud was the highest (12.5\%) in flipper isolates compared with $6.6 \%$ in boty isolates and very low $(0.5 \%)$ in the transposa group (Fig. 3B). Resistance to the succinate dehydrogenase inhibitor Flup was observed in none of the 262 isolates tested.

Overall, transposa and boty isolates had similar frequencies of isolates from similar multifungicide resistance (MFR) phenotypes (Fig. $3 C)$. Interestingly, boty isolates had a higher frequency ( $8.2 \%$ ) of isolates resistant to five fungicides (MFR5) compared with transposa (1.6\%) isolates (Fig. 3C), whereas only MFR1 and MFR2 phenotypes were detected in flipper isolates.

\section{Discussion}

The Botrytis population from strawberry in eastern North America and from blueberry in Florida is largely dominated by $B$. cinerea sensu stricto in all surveyed regions. Botrytis group S, a newly recognized clade from strawberry in Germany (Leroch et al. 2013), was found to coexist with $B$. cinerea on strawberry and blueberry in almost all regions surveyed. Our findings, together with recent reports from grape in New Zealand (Johnston et al. 2014), tomato in Greece (Konstantinou et al. 2015), and blackberry from the Carolinas ( $\mathrm{Li}$ et al. 2014), present evidence that Botrytis group $S$ is not host specific, as was initially believed (Leroch et al. 2013). In recent studies, a new species named $B$. fragariae was reported in strawberry fields in Germany and the Carolinas on the U.S. east coast (Dowling et al. 2017; Rupp et al. 2017). The occurrence of $B$. fragariae in other crops and its relationship with Botrytis group $S$ were not investigated by the authors and, therefore, Botrytis group $\mathrm{S}$ should be distinguished from $B$. fragariae. The above studies do not provide strong evidence for a clear host- or region-specific distribution of $B$. cinerea and Botrytis group S populations. Thus, B. cinerea was overwhelmingly predominant on both strawberry and blueberry in the Americas in this study and on strawberry in Greece (Konstantinou et al. 2015) but was less frequent than Botrytis group S in German strawberry fields (Leroch et al. 2013). Moreover, Botrytis group S was seldom found in German vineyards (Leroch et al. 2013) whereas it was common in New Zealand vineyards (Johnston et al. 2014). One hypothesis to explain the predominance of Botrytis group S in Germany strawberry fields may be related to the predominance of the MDRh1 sensitivity phenotype group in this region (Leroch et al. 2013). However, the reasons for the MDRh1 predominance in this region are not fully understood, given that spray regimes and types are not expected to be significantly different from other regions where strawberry are grown. To what extend different fitness abilities between the two Botrytis groups, different production systems (i.e., annual versus perennial), and weather conditions can explain such geographic variability remains unclear. Neither $B$. pseudocinerea nor $B$. caroliniana were found in the Americas, reinforcing their minor ecological status in the Botrytis genus (Isenegger et al. 2008; Kanetis et al. 2017; Samuel et al. 2012; Váczy et al. 2008). 
Studies of Botrytis genetic structure in North America are rare compared with studies of the European populations. Thus, only two reports were found in the literature, including one study from California that did not include small fruit (Ma and Michailides 2005) and another on 11 isolates from blueberry in Chile (Muñoz et al. 2002). Herein, Botrytis populations containing or not containing the TE boty and flipper were widespread across the Americas but at variable frequencies depending on the organ of collection. Transposa isolates, carrying both flipper and boty, were predominant on strawberry in North America, whereas boty isolates were slightly predominant $(56 \%)$ in Florida blueberry fields. Our findings agree with previous reports on the predominance of transposa isolates in almost all regions and crops investigated (i.e., grape, kiwi, tomato, and strawberry) (Giraud et al. 1999; Johnston et al. 2014; Kretschmer and Hahn 2008; Ma and Michailides 2005; Muñoz et al. 2002; Samuel et al. 2012; Váczy et al. 2008). We also present some evidence for seasonal variability in TE preponderance in relation to the phenological growth stage. Thus, boty isolates were predominant in populations collected early in the season from strawberry leaves (37 to $80 \%$ ) and blueberry flowers (53\%) whereas transposa-type isolates were overwhelmingly predominant (>73 to $94 \%$ ) in isolates collected from fruit later in the season regardless of the growing region. The dominance of transposa isolates on fruit was related to their higher aggressiveness on fruit, whereas vacuma isolates were suggested to be more saprophytic and fit to survive on leaves and other grape organs (Giraud et al. 1999; Martinez et al. 2003). The predominance of boty over vacuma isolates observed in small fruit in this study has been reported in other crops and regions (Johnston et al. 2014; Kretschmer and Hahn 2008; Ma and Michailides 2005; Milicevic et al. 2006; Váczy et al. 2008). Although different fitness abilities between transposa and boty isolates have not been investigated, one can speculate that boty isolates may act similarly to vacuma in term of aggressiveness to fruit, which could explain their relative lower frequency compared with transposa on fruit but higher on leaves and flowers. The geographic distribution of transposa and boty isolates seen in eastern North

Table 3. Overall frequency of different genotype groups of Botrytis from leaves, flowers, and fruit collected in Canada and the United States

\begin{tabular}{llccccc}
\hline & & \multicolumn{4}{c}{ Frequency (\%) } \\
\cline { 3 - 6 } & & & \multicolumn{3}{c}{ United States } \\
\cline { 3 - 7 } Genotype & Group & Canada & & Flowers & Leaves & Fruit \\
\cline { 3 - 4 } \cline { 5 - 6 } & Botrytis group & cinerea & 90.0 & 95.2 & 100.0 & 93.6 \\
& Group S & 10.0 & 4.8 & 0.0 & 6.4 \\
Transposable & transposa & 61.4 & 46.8 & 20.0 & 82.1 \\
& boty & 37.1 & 53.2 & 80.0 & 12.3 \\
& flipper & 0.0 & 0.0 & 0.0 & 4.3 \\
& Vacuma & 1.4 & 0.0 & 0.0 & 1.3 \\
\hline
\end{tabular}

${ }^{a}$ Overall frequency of different genetic groups found on each organ and country relative to the total number of isolates.

${ }^{b}$ Isolates from flowers are collected from strawberry and blueberry fields in Florida.

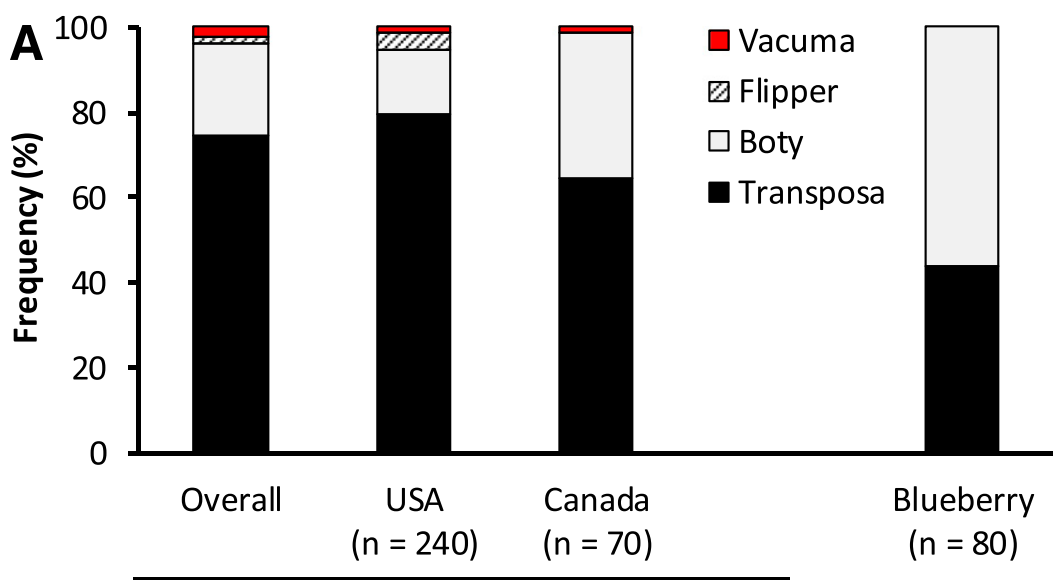

Strawberry

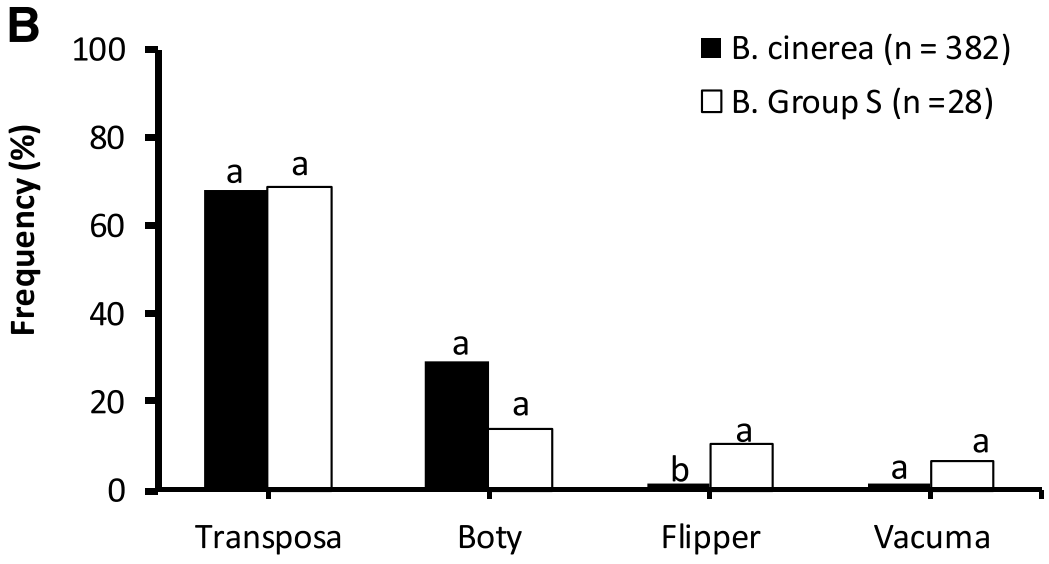

\section{Genetic element}

Fig. 2. Overall frequency of transposable elements (TE) A, by country and host and B, among Botrytis cinerea and Botrytis group $S$ in a population of 410 Botrytis isolates from strawberry (330) and blueberry (80) fields. Transposa isolates contain both boty and flipper elements, vacuma isolates lack both TE, and boty and flipper isolates contain only the boty or flipper element, respectively. 
America suggests that these genotypes are fit to survive under various weather conditions such as the ones occurring in Canada, the northern United States, or Florida.

Differences in resistance frequencies to fungicides commonly used to control gray mold in strawberry and blueberry fields were observed between $B$. cinerea sensu stricto and Botrytis group S. More isolates from the latter were sensitive than $B$. cinerea to almost all fungicides tested, except for Pyri and Flud. Although other studies reported sensitivity phenotypes similar to ours to a certain extent in strawberry isolates from greenhouses in Greece and Cyprus (Kanetis et al. 2017; Konstantinou et al. 2015), different phenotypes were found in German strawberry fields (Leroch et al. 2013). We found more Botrytis group $\mathrm{S}$ isolates sensitive to all fungicides, whereas resistance frequencies to Pyra, Bosc, Fenh, and Penth were higher in $B$. cinerea sensu stricto. On the other hand, the fact that reduced sensitivity to Flud and resistance to Pyri were higher in Botrytis group $\mathrm{S}$ indicates that these isolates may present some similarities with MDR1h phenotypes, which showed higher minimum inhibitory concentrations values

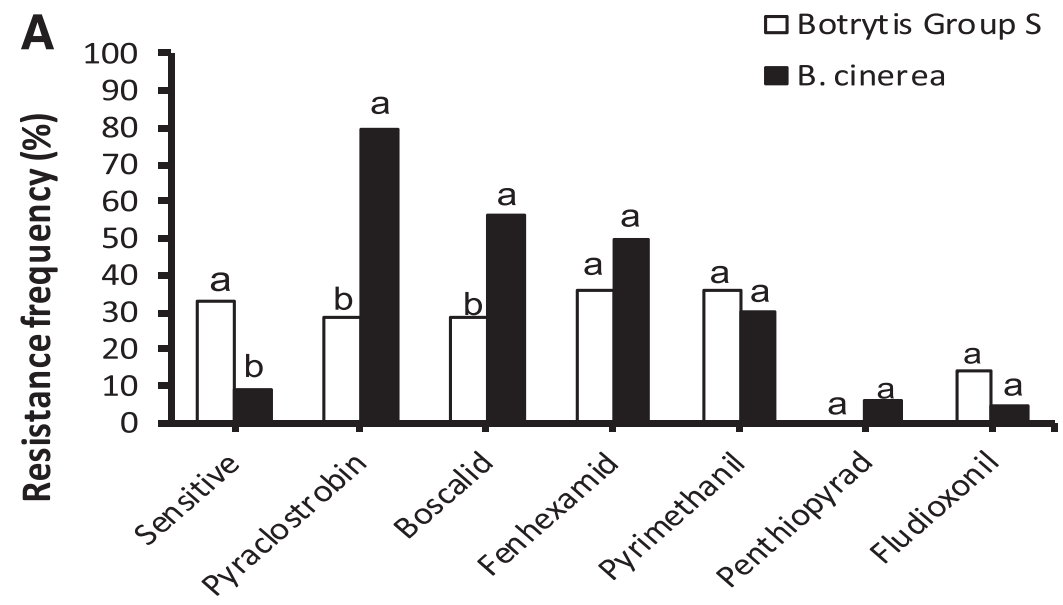

B

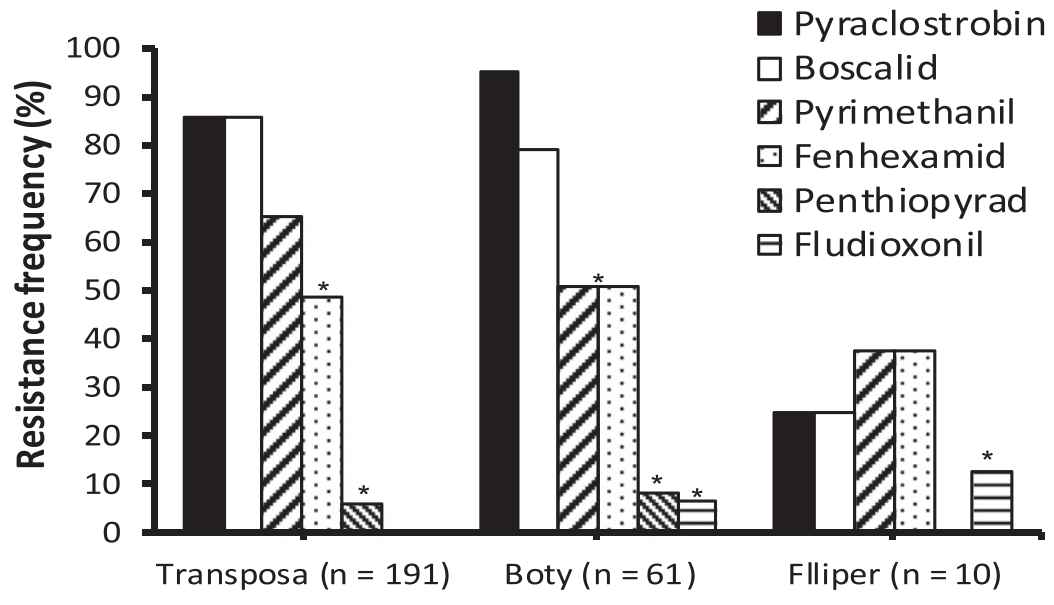

C

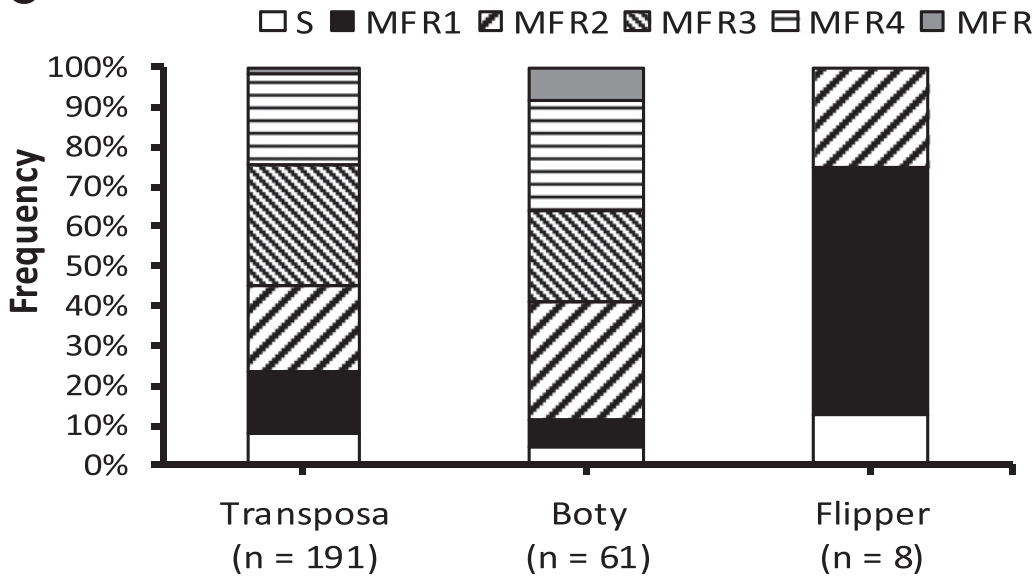

Transposable element

Fig. 3. A, Resistance frequencies of Botrytis cinerea sensu stricto and Botrytis group S; B, resistance frequencies in transposa, boty, and flipper isolates to six fungicides; and C, frequency of multifungicide resistance (MFR) phenotypes in Botrytis isolates $(n=268)$ from small fruit in Florida. S, MFR1, MFR2, MFR3, MFR4, and MFR5 indicate isolates sensitive or resistant to one, two, three, four, or five fungicides, respectively; asterisks $\left(^{*}\right)$ indicate significant differences. 
to Flud and cyprodinil compared with other phenotypes (Leroch et al. 2013). This suggests that multidrug resistance mechanisms may be causing resistance observed in strawberry and blueberry fields in Florida but at a significantly lower frequency than the ones reported in German populations. Moreover, despite differences in spray regimes between strawberry and blueberry fields in terms of spray frequency and fungicide types, we did not notice significant differences in resistance frequencies between $B$. cinerea and Botrytis group $\mathrm{S}$ from both hosts for all fungicides tested. In two recent studies, significant differences were observed between strawberry and tomato populations from greenhouses but not for all fungicides (Kanetis et al. 2017; Konstantinou et al. 2015). Whether population shifts and exposure to fungicides in open field populations, as in our study, are different from what may occur in greenhouse populations remains to be determined.

Transposa and boty isolates showed higher resistance frequencies than flipper isolates for all fungicides except Flud, for which flipper and boty isolates had higher resistance frequencies. Previous studies from grape focused on comparing resistance profiles in transposa and vacuma isolates to benzimidazole and dicarboxamides fungicides (Giraud et al. 1999; Martinez et al. 2005). These studies reported higher resistance frequencies in transposa compared with vacuma isolates. In the present study, we focused on fungicides commonly used in strawberry and blueberry and our findings indicate that the two major populations, transposa and boty, may possess a similar ability to develop resistance to most fungicides and that their management could be achieved by similar spray management programs. The low number of flipper isolates found in our study may not be enough to make major conclusions. However, it is interesting that more boty and flipper isolates have a reduced sensitivity to Flud than do transposa isolates. These findings may explain the low frequency of Flud-resistant isolates in strawberry and blueberry fields and may also entail a fitness penalty in flipper isolates similar to what was observed in field isolates resistant to Flud (Leroux et al. 2002). The role of these two TE in causing reduced sensitivity to Flud, specifically, requires further investigation.

The genetic structure of Botrytis spp. in the growing regions of strawberry may be highly defined and affected by continuous population migrations through nursery transplants. This high diversity together with the widespread resistance to multiple current fungicides may requires drastic changes in fungicide usage, including phasing out of those with high resistance frequencies, developing new molecules with different modes of action, and using some fungicides exclusively in the nurseries. Further studies focusing on the genetic populations and potential population drift are warranted to better understand and evaluate the risks.

\section{Acknowledgments}

This research was supported by a United States Department of Agriculture National Institute for Food and Agriculture fund under project number 201451181-22377. We thank R. Martin and Michelle Oliveira, Gulf Coast Research and Education Center, for technical help.

\section{Literature Cited}

Amiri, A., Heath, S. M., and Peres, N. A. 2013. Phenotypic characterization of multifungicide resistance in Botrytis cinerea isolates from strawberry fields in Florida. Plant Dis. 97:393-401.

Amiri, A., Heath, S. M., and Peres, N. A. 2014. Resistance to fluopyram, fluxapyroxad, and penthiopyrad in Botrytis cinerea from strawberry. Plant Dis. 98:532-539.

Amiri, A., Mulvaney, K. A., and Pandit, L. K. 2017. First report of resistance to fluxapyroxad and fluopyram in Botrytis cinerea from commercial apple orchards in Washington State. Plant Dis. 101:508.

Beever, R. E., and Parkes, S. L. 2003. Use of nitrate non-utilising (Nit) mutants to determine vegetative compatibility in Botryotinia fuckeliana (Botrytis cinerea). Eur. J. Plant Pathol. 109:607-613.

Beever, R. E., and Weeds, P. L. 2004. Taxonomy and genetic variation of Botrytis and Botryotinia. Pages 29-52 in: Botrytis: Biology, Pathology and Control. Y. Elad, B. Williamson, P. Tudzynski, and N. Delen, eds. Springer, Dordrecht, The Netherlands.

Castro, M., Kramer, K., Valdivia, L., Ortiz, S., and Castillo, A. 2003. A doublestranded RNA mycovirus confers hypovirulence-associated traits to Botrytis cinerea. FEMS Microbiol. Lett. 228:87-91.

Diolez, A., Marches, F., Fortini, D., and Brygoo, Y. 1995. Boty, a long terminalrepeat retroelement in the phytopathogenic fungus Botrytis cinerea. Appl. Environ. Microbiol. 61:103-108.
Dowling, M. E., Hu, M. J., and Schnabel, G. 2017. Identification and characterization of Botrytis fragariae isolates on strawberry in the United States. Plant Dis. 101: 1769-1773.

Fournier, E., Levis, C., Fortini, D., Leroux, P., Giraud, T., and Brygoo, Y. 2003. Characterization of Bc-hch, the Botrytis cinerea homolog of the Neurospora crassa het-c vegetative incompatibility locus, and its use as a population marker. Mycologia 95:251-261.

Giraud, T., Fortini, D., Levis, C., Lamarque, C., Leroux, P., LoBuglio, K., and Brygoo, Y. 1999. Two sibling species of the Botrytis cinerea complex, transposa and vacuma, are found in sympatry on numerous host plants. Phytopathology 89: 967-973.

Giraud, T., Fortini, D., Levis, C., Leroux, P., and Brygoo, Y. 1997. RFLP markers show genetic recombination in Botryotinia fuckeliana (Botrytis cinerea) and transposable elements reveal two sympatric species. Mol. Biol. Evol. 14: $1177-1185$

Groves, J. W., and Loveland, C. A. 1953. Connection between Botryotinia fuckeliana and Botrytis cinerea. Mycologia 45:415-425.

Hiratsuka, K., Namba, S., Yamashita, S., and Doi, Y. 1987. Linear plasmid-like DNA's in the fungus Botrytis cinerea. Ann. Phytopathol. Soc. Jpn. 53: 638-642.

Isenegger, D. A., Ades, P. K., Ford, R., and Taylor, P. W. J. 2008. Status of the Botrytis cinerea complex and microsatellite analysis of transposon types in South Asia and Australia. Fungal Divers. 29:17-27.

Johnston, P. R., Hoksbergen, K., Park, D., and Beever, R. E. 2014. Genetic diversity of Botrytis in New Zealand vineyards and the significance of its seasonal and regional variation. Plant Pathol. 63:888-898.

Kanetis, L., Christodoulou, S., and Iacovides, T. 2017. Fungicide resistance profile and genetic structure of Botrytis cinerea from greenhouse crops in Cyprus. Eur. J. Plant Pathol. 147:527-540.

Kecskeméti, E., Brathuhn, A., Kogel, K. H., Berkelmann-Löhnertz, B., and Reineke, A. 2014. Presence of transposons and mycoviruses in Botrytis cinerea isolates collected from a German grapevine growing region. J. Phytopathol 162:582-595.

Kidwell, M. G., and Linch, D. R. 2001. Perspective: Transposable elements, parasitic DNA, and genome evolution. Evolution 55:1-24.

Konstantinou, S., Veloukas, T., Leroch, M., Menexes, G., Hahn, M., and Karaoglanidis, G. 2015. Population structure, fungicide resistance profile, and $s d h B$ mutation frequency of Botrytis cinerea from strawberry and greenhousegrown tomato in Greece. Plant Dis. 99:240-248.

Kretschmer, M., and Hahn, M. 2008. Fungicide resistance and genetic diversity of Botrytis cinerea isolates from vineyard in Germany. J. Plant Dis. Prot. 115: 214-219.

Leroch, M., Plesken, C., Weber, R. W. S., Kauff, F., Scalliet, G., and Hahn, M 2013. Gray mould populations in German strawberry fields are resistant to multiple fungicides and dominated by a novel clade closely related to Botrytis cinerea. Appl. Environ. Microbiol. 79:159-167.

Leroux, P., Fritz, R., Debieu, D., Albertini, C., Lanen, D., Bach, J., Gredt, M., and Chapland, F. 2002. Mechanisms of resistance to fungicides in field strains of Botrytis cinerea. Pest Manage. Sci. 58:876-888.

Levis, C., Fortini, D., and Brygoo, Y. 1997. Flipper, a mobile Fot1-like transposable element in Botrytis cinerea. Mol. Gen. Genet. 254:674-680.

Li, X., Fernández-Ortuño, D., Chai, W., Wang, F., and Schnabel, G. 2012. Identification and prevalence of Botrytis spp. from blackberry and strawberry fields of the Carolinas. Plant Dis. 96:1634-1637.

Li, X., Fernández-Ortuño, D., Grabke, A., and Schnabel, G. 2014. Resistance to fludioxonil in Botrytis cinerea isolates from blackberry and strawberry. Phytopathology 104:724-732.

Ma, Z., and Michailides, T. J. 2005. Genetic structure of Botrytis cinerea populations from different host plants in California. Plant Dis. 89: 1083-1089.

Martinez, F., Blancard, D., Lecomte, P., and Levis, C. 2003. Phenotypic differences between vacuma and transposa subpopulations of Botrytis cinerea. Eur. J. Plant Pathol. 109:479-488.

Martinez, F., Dubos, B., and Fermaud, M. 2005. The role of saprotrophy and virulence in the population dynamics of Botrytis cinerea in vineyards. Phytopathology 95: 692-700.

Milicevic, T., Topolovec-Pintaric, S., Cvjetkovic, B., Ivic, D., and Duralija, B. 2006. Sympatric populations of Botrytis cinerea on strawberries based on the content of transposable elements and their connection with resistance to botryticides. Acta Hortic. 708:115-118.

Muñoz, G., Hinrichsen, P., Brygoo, Y., and Giraud, T. 2002. Genetic characterization of Botrytis cinerea populations in Chile. Mycol. Res. 106:594-601.

Oliveira, M. S., Amiri, A., and Peres, N. A. 2013. The role of nursery plants as a potential source of inoculum for Botrytis cinerea and its impact on fungicide sensitivity. (Abstr.) Phytopathology 103:S2.107.

Oliveira, M. S., Amiri, A., Zuniga, A. I., and Peres, N. A. 2017. Sources of primary inoculum of Botrytis cinerea and their impact on fungicide resistance development in commercial strawberry fields. Plant Dis. 101:1761-1768.

Rahman, M., Ojiambo, P., and Louws, F. 2015. Initial inoculum and spatial dispersal of Colletotrichum gloeosporioides, the causal agent of strawberry anthracnose crown rot. Plant Dis. 99:80-86.

Rupp, S., Plesken, C., Rumsey, S., Dowling, M., Schnabel, G., Weber, R. W. S., and Hahn, M. 2017. Botrytis fragariae, a new species causing gray mold on 
strawberries, shows high frequencies of specific and efflux-based fungicide resistance. Appl. Environ. Microbiol. 83:e00269-17.

Saito, S., Michailides, T. J., and Xiao, C. L. 2014. First report of Botrytis pseudocinerea causing gray mold on blueberry in North America. Plant Dis. 98:1743.

Samuel, S., Veloukas, T., Papavasileiou, A., and Karaoglanidis, G. S. 2012. Differences in frequency of transposable elements presence in Botrytis cinerea populations from several hosts in Greece. Plant Dis. 96:1286-1290.

Smith, R. E. 1900. Botrytis and Sclerotinia; their relation to certain plant diseases and to each other. Bot. Gaz. 29:369-407.
Váczy, K. Z., Sándor, E., Karaffa, L., Fekete, E., Fekete, É., Árnyasi, M., Czeglédi, L., Kövics, G. J., Druzhinina, I. S., and Kubicek, C. P. 2008. Sexual recombination in the Botrytis cinerea populations in Hungarian vineyards. Phytopathology 98:1312-1319.

Walker, A. S. 2016. Diversity within and between species of Botrytis. Pages 91-125 in: Botrytis - The Fungus, the Pathogen and Its Management in Agricultural Systems. S. Fillinger and Y. Elad, eds. Springer International Publishing, Cham, Switzerland. Weber, R. W., and Hahn, M. 2011. A rapid and simple method for determining fungicide resistance in Botrytis. J. Plant Dis. Prot. 118:17-25. 